Bakermans, M., B. W. Smith, B. C. Jones, and J. L. Larkin. 2015. Stand and within-stand factors influencing Golden-winged Warbler use of regenerating stands in the central Appalachian Mountains. Avian Conservation and Ecology 10(1): 10. http://dx.doi.org/10.5751/ACE-00747-100110 Copyright (C 2015 by the author(s). Published here under license by the Resilience Alliance.

\title{
Stand and within-stand factors influencing Golden-winged Warbler use of regenerating stands in the central Appalachian Mountains
}

\author{
Marja H. Bakermans ${ }^{1}$, Brian W. Smith ${ }^{2}$, Benjamin C. Jones ${ }^{3}$ and Jeffery L. Larkin ${ }^{4}$ \\ ${ }^{1}$ Worcester Polytechnic Institute, ${ }^{2}$ U.S. Fish and Wildlife Service, ${ }^{3}$ Pennsylvania Game Commission, ${ }^{4}$ Indiana University of \\ Pennsylvania
}

\begin{abstract}
The Golden-winged Warbler (Vermivora chrysoptera) is currently being considered for protected status under the U.S. Endangered Species Act. The creation of breeding habitat in the Appalachian Mountains is considered a conservation priority for this songbird, which is dependent on extensively forested landscapes with adequate availability of young forest. We modeled abundance of Golden-winged Warbler males in regenerating harvested forest stands that were 0-17 years postharvest at both mid-Appalachian and northeast Pennsylvania regional scales using stand and within-stand characteristics of 222 regenerating stands, 2010-2011. Variables that were most influential at the mid-Appalachian scale were different than those in the northeast region. Across the mid-Appalachian ecoregion, the proportion of young forest cover, i.e., shrub/scrub cover, within $1 \mathrm{~km}$ of regenerating stands best explained abundance of Golden-winged Warblers. Golden-winged Warbler response was best explained by a concave quadratic relationship in which abundance was highest with 5-15\% land in young forest cover. We also found evidence that the amount of herbaceous cover, i.e., the amount of grasses and forbs, within a regenerating stand positively influenced abundance of Golden-winged Warblers. In northeastern Pennsylvania, where young forest cover is found in high proportions, the distance to the nearest regenerating stand best explained variation in abundance of Golden-winged Warblers. Abundance of Golden-winged Warblers was $<1$ male per survey when another regenerating stand was $>1500 \mathrm{~m}$ away. When modeling within-stand features in the northeast region, many of the models were closely ranked, indicating that multiple variables likely explained Golden-winged Warbler response to within-stand conditions. Based on our findings, we have proposed several management guidelines for land managers interested in creating breeding habitat for Golden-winged Warblers using commercial timber operations. For example, we recommend when managing for Golden-winged Warblers in the central Appalachian Mountains that managers should strive for $15 \%$ young forest in a heavily forested landscape ( $>70 \%$ forest cover) and cluster stands within 1-2 km of other young forest habitats.
\end{abstract}

\section{Caractéristiques de peuplements et intra-peuplements ayant une influence sur l'utilisation de peuplements en régénération par la Paruline à ailes dorées dans le secteur centre des Appalaches}

RÉSUMÉ. La Paruline à ailes dorées (Vermivora chrysoptera) est présentement sur la liste des espèces candidates pour l'obtention d'un statut de protection en vertu de la Endangered Species Act (loi sur les espèces en péril) aux États-Unis. La création de milieux de nidification dans les Appalaches est vue comme une priorité de conservation pour ce passereau, qui dépend de vastes paysages boisés pourvus de jeunes forêts adéquates. Nous avons modélisé l'abondance de Parulines à ailes dorées mâles dans des peuplements forestiers en régénération après récolte, âgés de 0 à 17 ans, à l'échelle régionale des Appalaches du Centre et du nord-est de la Pennsylvanie, au moyen de caractéristiques de peuplements et intra-peuplements de 222 peuplements en régénération, 2010-2011. Les variables qui avaient le plus d'influence à l'échelle des Appalaches du Centre étaient différentes de celles à l'échelle du Nord-Est. Dans l'écorégion des Appalaches du Centre, la proportion du couvert en jeunes forêts, c.-à-d. couvert en milieux arbustifs, dans un rayon de $1 \mathrm{~km}$ de peuplements en régénération expliquait le mieux l'abondance de cette paruline. La présence de la Paruline à ailes dorées était le mieux expliquée par une relation quadratique concave dans laquelle l'abondance était maximale dans les paysages où se trouvait de 5 à $15 \%$ de jeunes forêts. Nous avons également obtenu des indices que la quantité de couvert en herbacées, c.-à-d. la quantité de graminées et d'herbacées non graminoïdes, dans un peuplement en régénération avaient une influence positive sur l'abondance de cette espèce. Dans le nord-est de la Pennsylvanie, où la proportion de jeunes forêts est élevée, la distance au peuplement en régénération le plus près expliquait le mieux la variabilité de l'abondance de la Paruline à ailes dorées. L'abondance de Parulines à ailes dorées était inférieure à 1 mâle par inventaire dans les cas où le peuplement en régénération le plus près se trouvait à plus de $1500 \mathrm{~m}$. Lors de la modélisation des caractéristiques intra-peuplements dans la région du nord-est, bon nombre de modèles obtenaient un score similaire, ce qui indique que des variables multiples expliquaient vraisemblablement la réponse de la Paruline à ailes dorées aux caractéristiques intrapeuplements. À partir de nos résultats, nous avons proposé plusieurs lignes directrices d'aménagement destinées aux gestionnaires de terres intéressés à créer des milieux de nidification pour la Paruline à ailes dorées au moyen d'activités de récolte commerciales. Par exemple, pour l'aménagement de l'habitat de la Paruline à ailes dorées dans les Appalaches du Centre, nous recommandons aux gestionnaires de tendre vers l'obtention de $15 \%$ de jeunes forêts dans un paysage fortement boisé (couverture supérieure à $70 \%$ ) et de regrouper les peuplements dans un rayon de 1 à $2 \mathrm{~km}$ d'autres jeunes milieux forestiers.

Key Words: forest regeneration; landscape; Maryland; Pennsylvania; silviculture; Vermivora chrysoptera; young forest

Address of Correspondent: Marja H Bakermans, Department of Biology and Biotechnology, Worcester Polytechnic Institute, 100 Institute Road, Worcester, MA 01609-2280, mbakermans@wpi.edu 


\section{INTRODUCTION}

The Golden-winged Warbler (Vermivora chrysoptera) is a migratory songbird that nests in deciduous young forests, shrublands, and woody wetlands of eastern North America (Confer et al. 2011). Young forests have a diverse vegetation structure and composition that contains a mix of grasses, forbs, shrubs, saplings, and scattered trees, and in regenerating forests, this period lasts for approximately 15-20 years postharvest (Thompson and DeGraaf 2001). The once contiguous breeding distribution of this species now consists of 2 disjunct subpopulations: Appalachian and Great Lakes populations (Roth et al. 2012). Golden-winged Warbler populations in the Appalachian Mountains have exhibited considerable range contraction (Confer et al. 2011) and precipitous annual population declines of $8.5 \%$ per year since the initiation of Breeding Bird Surveys in 1966 (Sauer et al. 2014). Although loss of breeding habitat is thought to be a key limiting factor for this imperiled species, competition and hybridization with a close relative, the Blue-winged Warbler (Vermivora cyanoptera), which may overlap in breeding habitat, is also a threat (Buehler et al. 2007, Vallender et al. 2009, Confer et al. 2011). As such, the development of management prescriptions that create or maintain Golden-winged Warbler breeding habitat in areas devoid of Blue-winged Warblers is a conservation priority (Buehler et al. 2007, Patton et al. 2010).

The amount of young forest, shrublands, and forested wetlands used by the Golden-winged Warbler and other species associated with these communities is no longer available to the extent needed for long-term population viability (Buffum et al. 2011). Historically, young forests and shrublands were created from natural disturbance regimes, such as wind, fire, insect outbreaks, and beaver (Castor canadensis) activity (Lorimer and Frelich 1994, Litvaitis et al. 1999, Brawn et al. 2001). From the 1860s to 1940 s, a large amount of young forest was made available through succession on abandoned farmland and regeneration from timber harvesting (Masek et al. 2011). However, forest maturation, the suppression and alteration of some natural disturbances, and reduction in the amount of abandoned farmland has resulted in a shortage of young forest across the Appalachians (Smith 2007). Klaus and Buehler (2001) predicted that forest succession in the absence of forest harvesting methods, e.g., overstory removal, at suitable elevations and forest types would soon eliminate Goldenwinged Warbler habitat in their southern Appalachian study sites.

Although natural disturbances and human-generated shrublands, i.e., utility rights-of-way, will create some breeding habitat, forest harvesting methods within the Appalachian Mountains' 55 million ha of forest cover (Smith et al. 2009) will be needed to sustain Golden-winged Warbler populations. Forest harvesting methods provide a practical approach to increasing the amount of young forests to complement natural disturbance regimes (Litvaitis 2003). In fact, harvesting of forests is the largest mechanism to creating young forest in the eastern United States (Masek et al. 2013). Thus, with the resurgence of forest harvesting in the central Appalachian Mountains (Smith 2007), there is a real opportunity to develop regional forest management guidelines that consider Golden-winged Warbler breeding ecology.

The habitat selection process by organisms, especially migratory birds, occurs on multiple spatial scales, starting at large, e.g., landscape, scales followed by selections at smaller, e.g., stand or territory, scales (Johnson 1980, Hutto 1985, Jones 2001). Indeed, in areas of limited habitat, landscape characteristics may constrain habitat selection processes at smaller spatial scales (Bakermans and Rodewald 2006). For example, the landscape matrix and amount of available habitat can influence diversity and abundance of breeding birds in forest stands (Robbins et al. 1989, Hagan et al. 1997, Rodewald and Yahner 2001). Because Golden-winged Warblers respond to features across multiple spatial scales (Thogmartin 2010), management efforts will need to explicitly consider a variety of attributes to effectively stabilize the population and ultimately reverse declines.

Although the Appalachian Mountains population of Goldenwinged Warblers is estimated to represent only approximately $5 \%$ of the global population, there are reasons for conserving this population (Roth et al. 2012). For example, the Appalachian population has experienced the northward expansion of, and hybridization with, Blue-winged Warblers (Buehler et al. 2007). Consequently, remaining Golden-winged Warbler population strongholds have been able to coexist in areas with Blue-winged Warblers through the segregation of species by habitat (Confer et al. 1998, 2010), elevation (Buehler et al. 2007), or percent forest cover in the landscape (Thogmartin 2010). In continued efforts to improve conservation of Golden-winged Warblers, our research sought to develop management recommendations for natural resource practitioners interested in creating breeding habitat for Golden-winged Warblers through forest harvesting methods in the central Appalachian Mountains. Our objectives were to study habitat use of Golden-winged Warblers across a range of regenerating harvested forest stands, hereafter referred to as regenerating stands, so that we could model bird-habitat relationships to inform management guidelines. Specifically, we (1) quantified and compared characteristics across a range of regenerating stands among regions and where Golden-winged Warblers were and were not detected and (2) used stand and within-stand variables to model male Golden-winged Warbler apparent abundance in regenerating stands at both midAppalachian and northeast Pennsylvania regional spatial scales.

\section{METHODS}

\section{Study area}

We focused our survey efforts in areas of known concentrations of breeding Golden-winged Warblers in Pennsylvania and western Maryland based on results from the first and second Maryland and Pennsylvania breeding bird atlases (Brauning 1992, Robbins 1996, Ellison 2010, Wilson et al. 2012). This study area falls in the mid-Appalachian Mountains ecoregion and within the conservation focal areas identified in the Goldenwinged Warbler conservation plan (Roth et al. 2012; see Fig. 1). Current population estimates for Golden-winged Warblers in Pennsylvania and Maryland range from 5000 to 7600 singing males, the second highest population in the Appalachians (Ellison 2010, Larkin and Bakermans 2012, Partners in Flight Science Committee 2013). Pennsylvania and Maryland are unique in that $>2.3$ million ha of public and privately owned forestland exists within the portions of these states, which have been identified as Golden-winged Warbler conservation focal areas. Additionally, both states have government agencies, e.g., Pennsylvania Game Commission and Bureau of Forestry and Maryland Department 
Fig. 1. Mid-Appalachian ecoregion and the boundary of the conservation focal areas (shaded regions) of Golden-winged Warbler (Vermivora chrysoptera) habitat management in Pennsylvania and western Maryland with south-central (top left), north-central (top center), and northeast (top right) study regions. The locations of regenerating stands used in the study are indicated with triangles.
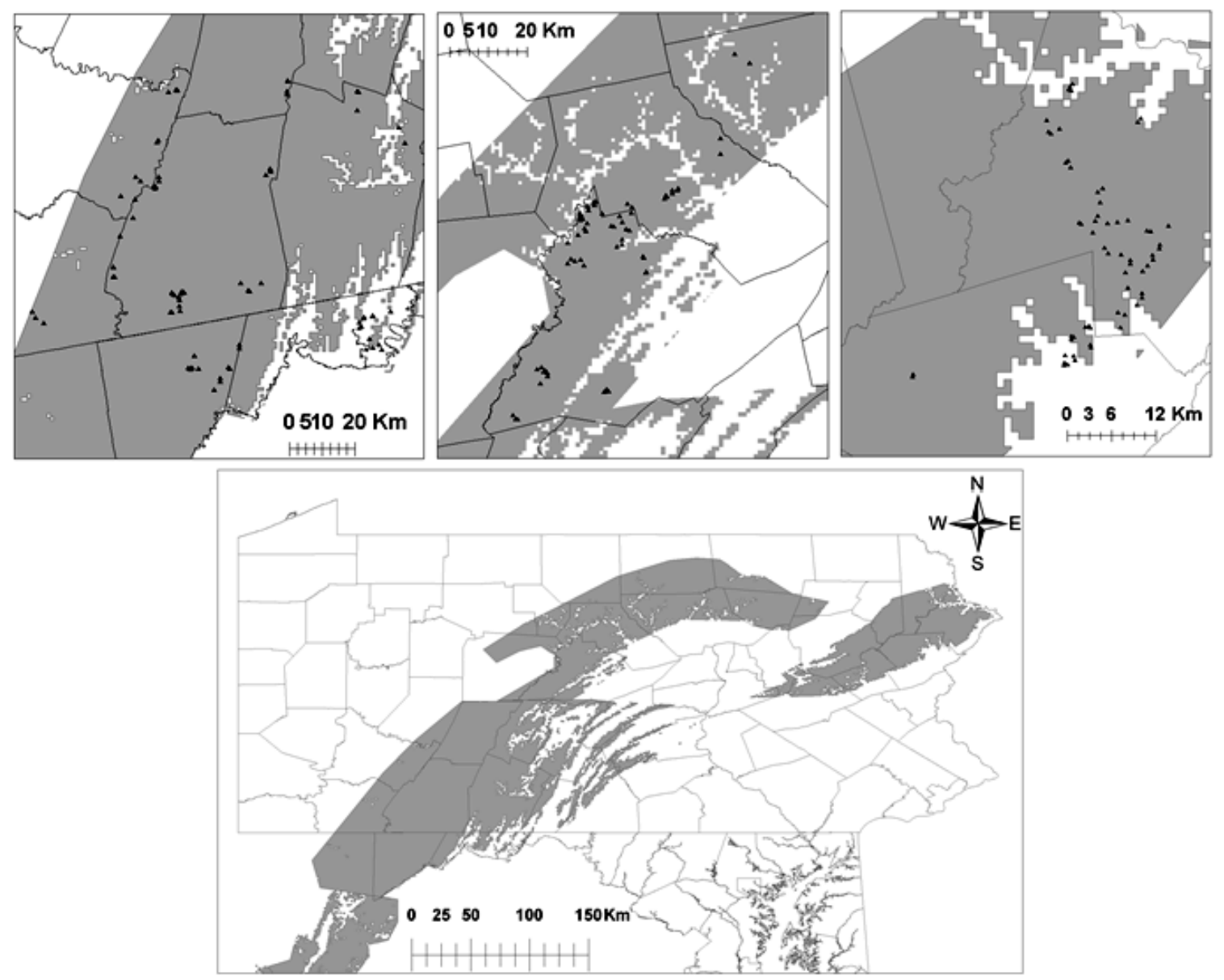

of Natural Resources, and private conservation groups, e.g., The Nature Conservancy, that are actively promoting the creation of young forest via commercial silvicultural regeneration methods and the restoration of ecological systems, e.g., scrub oak shrubland (Fike 1999), using noncommercial treatments such as prescribed fire. Thus, Pennsylvania and Maryland play an important role in maintaining and building populations of Golden-winged Warblers in the central Appalachian Mountains.

We studied 3 regions: (1) north-central Pennsylvania, hereafter referred to as north-central region; (2) northeast Pennsylvania, hereafter referred to as northeast region; and (3) south-central Pennsylvania and western Maryland, hereafter referred to as south-central region (Fig. 1). These sites were located on public lands, i.e., $68 \%$ on state forests and $28 \%$ on state game lands, and private lands, i.e., $5 \%$ on a private hunting and fishing club. Collectively, we refer to all 3 study regions as the mid-Appalachian region. Study sites in the north-central region were located within the Mountainous High Allegheny Plateau physiographic province (Fenneman 1938, Sevon 2000), which was characterized by high ridges and deep valleys and was predominately northern hardwood or dry oak forest (Quercus spp.; Fike 1999). The mean elevation of the regenerating stands that we included was $550 \mathrm{~m}$ (range $=409-668 \mathrm{~m}$ ). Study sites located in the northeast region were within the Appalachian Glaciated Low Plateau physiographic province (Fenneman 1938, Sevon 2000), which is characterized by rounded hills and valleys. The mean elevation for regenerating stands surveyed in this region was $408 \mathrm{~m}$ (range $=275-563 \mathrm{~m}$ ). The forests in the northeast region were dominated by oak-heath and northern hardwood forests, $80+$ years postharvest (Fike 1999), interspersed with wetlands, swamps, and urban and suburban areas. Study sites in the south-central region were located within the Allegheny Front, Appalachian Mountain, and Ridge and Valley physiographic provinces (Fenneman 1938, Sevon 2000, Reger and Cleaves 2008). Forest composition was a mix of northern hardwoods and oak-hickory and dry oak forests with pockets of scrub oak-pitch pine and was characterized by undulating ridges and valleys (Fike 1999). The mean elevation of regenerating stands surveyed in the south-central region was 706 $\mathrm{m}($ range $=293-946 \mathrm{~m})$.

\section{Stand selection}

Based on data, e.g., shapefiles of recently harvested stands, obtained from land managers from the Pennsylvania Department 
of Conservation and Natural Resources Bureau of Forestry, the Pennsylvania Game Commission, Blooming Grove Hunting and Fishing Club, and Maryland Department of Natural Resources, we created GIS-based maps to identify appropriate regenerating stands to survey. We then randomly selected a subset of existing regenerating stands to survey based on the following criteria: time since harvest (i.e., $0-17$ years postharvest, $5.4 \pm 0.3$ years postharvest, mean \pm standard error $)$, residual basal area $\left(0-18 \mathrm{~m}^{2} /\right.$ ha), and location in the region (see Fig. 1). We then used HawthsTools (http://www.spatialecology.com/htools) in ArcMap 10.0 (ESRI, Redlands, California) to create a grid of points, with $250 \mathrm{~m}$ distance separation, over each study region and identified avian point counts that were located at each grid point within the randomly selected regenerating stands. We restricted regenerating stands to contain 1-2 point counts because we wanted to place greater effort in sampling a range of regenerating stands. If a stand contained more than 1 point count, we randomly selected 1 point count to represent that stand in analyses. All of the regenerating stands we surveyed were dominated by hardwoods, created through regular commercial operations, e.g., overstory removal, and none were planted restorations.

\section{Bird surveys}

We conducted bird surveys from 10 May to 15 June 2010 and 2011 via point-count methods (modified from Gregory et al. 2004). All observations occurred between sunrise and 1100 hours EST in favorable weather conditions. Each point count was visited 2-3 times per season with 4-7 d between surveys. Over a 10-min period, we recorded each Golden-winged Warbler, Blue-winged Warbler, and Golden-winged $\times$ Blue-winged Warbler hybrid, e.g., Brewster's Warbler. We recorded birds by sight and sound and included the sex and activity, e.g., singing, of each bird as well as distance with a range finder from the center point. Visual confirmation of birds was important given the potential of hybrids using the same habitats. Thus, once the point count was complete, each observer used playback of a Golden-winged Warbler song until achieving positive visual confirmation of each individual by plumage characteristics, e.g., black throat, and behavior, e.g., singing. However, it should be noted that even with the confirmation of a phenotypic Golden-winged Warbler, there likely exists cryptic hybridization in the Golden-winged Warbler population we studied (Vallender et al. 2009).

\section{Habitat characteristics}

\section{Stand features}

Characteristics of each regenerating stand and its surrounding landscape, hereafter referred to as stand characteristics, were quantified using geographically referenced, i.e., GIS, data layers acquired from state agencies and private land cooperators. Variables we recorded include amount of each land cover class within $1 \mathrm{~km}$ of the centroid of each regenerating stand, stand size, years since harvest, mean perimeter-to-area ratio, stand edge, distance to another regenerating stand, and elevation. We quantified these features using ArcGIS extension Patch Analyst (Rempel et al. 2012). Land cover types were quantified and classified using the National Land Cover Database (Fry et al. 2011). We quantified the following land cover types: forest, i.e., deciduous forest cover; urban cover, i.e., a combination of all developed lands; young forest, i.e., shrub/scrub; and wetland, i.e., woody wetlands.

\section{Within-stand features}

For all stands in the northeast region and for a randomly selected subset of stands in the north-central and south-central regions, we revisited each point count after bird surveys were completed to sample vegetation. Because of time and personnel constraints, we placed more effort on vegetation sampling in the region, i.e., northeast, that had the greatest numbers of Golden-winged Warblers. We quantified vegetation at each point count where the point location served as the center of sampling with $\geq 30$ vegetation sampling plots of $1 \mathrm{~m}$ radius positioned approximately $12 \mathrm{~m}$ apart along lines oriented in random directions, $120^{\circ}$ apart, and within $125 \mathrm{~m}$ of the center point. This $125 \mathrm{~m}$ radius area (i.e., $4.9 \mathrm{ha}$ ) approximates the size of 1-2 Golden-winged Warbler territories (Confer et al. 2011). We followed a standard sampling protocol developed by the Golden-winged Warbler Working Group (GWWG) to allow for comparison across the breeding range. We collected the following variables within each $1 \mathrm{~m}$ radius plot: percent cover of (1) grasses; (2) forbs; (3) ferns; (4) Rubus spp., i.e., blackberry; (5) Solidago spp., i.e., goldenrod; (6) most common shrub; (7) second most common shrub; (8) third most common shrub; (9) surface water; (10) bare ground; (11) shrubs <1 m; (12) shrubs $>1 \mathrm{~m}$; (13) saplings $<10 \mathrm{~cm}$ diameter at breast height (dbh); (14) canopy cover contributed by trees $>10 \mathrm{~cm} \mathrm{dbh}$; and (15) distance (m) to a microedge. Microedge was defined as an obvious change in vegetation height or composition, e.g., a transition from grass to bare ground. The first 10 variables were measured as the percent of that variable within the plot and summed to $100 \%$. Tree canopy was estimated as the percent of the plot that was shaded by overhead tree foliage. At every fifth sampling point $(n=6)$, we estimated residual basal area using a 10 -factor prism, number of snags $(>1.4 \mathrm{~m}$ in height, $>12 \mathrm{~cm}$ dbh) within $11.3 \mathrm{~m}$ radius plot, shrub and sapling species, number of shrubs 1-2 $\mathrm{m}$ tall, number of shrubs $>2 \mathrm{~m}$ tall, and number of saplings $(>1 \mathrm{~cm}$ and $<10 \mathrm{~cm} \mathrm{dbh}$ and $>0.5 \mathrm{~m}$ tall) within a $5 \mathrm{~m}$ radius plot. In 2011, we also recorded the number of residual trees $(>10 \mathrm{~cm} \mathrm{dbh})$ within the entire pointcount plot (125 m radius plot) and the diameter of those residuals. Residual tree diameter classes were recorded for small $(10-23 \mathrm{~cm}$ $\mathrm{dbh})$, medium (23.1-38 $\mathrm{cm} \mathrm{dbh})$, and large ( $>38.1 \mathrm{~cm} \mathrm{dbh})$ trees.

\section{Analyses}

We derived an apparent abundance index, hereafter referred to as abundance, for male Golden-winged Warblers from the maximum number of individuals counted across point-count visits at each regenerating stand (Toms et al. 2006). Because few sites were visited in both years and there were no annual differences in number of individuals counted in those stands $\left(t_{35}=0.28, P=0.782\right)$, we used the maximum number of individuals counted at each point over the 2 years. We did not use distance-based measures to adjust our point count-derived abundance measures for the following reasons: (1) we did not expect detection differences based on habitat given that similar regeneration methods were used throughout the study area; (2) repeated visits increased availability for detection (Dettmers et al. 1999); (3) playback used after each point count indicated that detection rates were high, i.e., only 1 time each year did we detect a bird during playback that was not detected during the point count; and (4) studies have shown that distance sampling can increase bias and reduce precision under certain conditions, e.g., with uncommon species (Johnson 2008, Efford and Dawson 2009).

To select variables for analyses, we used information derived from published literature (e.g., Confer et al. 2011) and expert opinion 
deemed important by the GWWG (http://gwwa.org/resources/ Workshop_overview_V1.5.docx). We combined percent cover of grasses and forbs to create 1 variable we called herbaceous cover. We then used Spearman's correlation analysis to identify variables that were highly correlated (e.g., $r \geq 0.60$ ), and we removed 1 variable from each correlated pair from analyses. For example, percent woody wetland cover was removed from analyses because it was highly correlated with young forest cover $(r=0.64, P<$ 0.001). We compared stand and, separately, within-stand variables where Golden-winged Warblers were and were not detected with a multivariate analysis of variance (MANOVA). We also compared regional differences with a MANOVA. Stand variables we retained for analyses included urban, forest, and young forest land cover classes within $1 \mathrm{~km}$ of each regenerating stand; stand size; stand age; mean perimeter-to-area ratio; and distance to another regenerating stand. Within-stand variables in analyses included percent cover of herbaceous vegetation, percent cover of shrubs, numbers of saplings per hectare, shrubs per hectare, residual basal area, and distance to microedge. We square root transformed dependent variables that were not normal. Visual inspection of normal probability plots for each dependent variable indicated that transformations reduced deviations from normality, and MANOVA analyses are resistant to nonnormality (Zar 1999). Based on breeding biology, we hypothesized that numbers of Golden-winged Warblers would be negatively related to urban land cover (Friesen et al. 1995, Rodewald and Bakermans 2006) and distance to the nearest regenerating stand (Streby et al. 2012, Frantz et al., in press) but positively related to mean perimeter-to-area ratio (Klaus and Buehler 2001, Rossell et al. 2003), forest and young forest land covers (Thogmartin 2010, Roth et al. 2012), and size of stand (Kubel and Yahner 2008). We predicted that warbler abundance would have a quadratic relationship to time since harvest (Klaus and Buehler 2001, Bulluck and Buehler 2008). Furthermore, we expected that warbler abundance would be positively related to herbaceous cover (Klaus and Buehler 2001, Confer et al. 2003, Bulluck and Buehler 2008, Aldinger 2010), sapling density (Roth and Lutz 2004, Martin et al. 2007), and shrub cover (Confer et al. 2003, Martin et al. 2007, Aldinger and Wood 2014) but negatively related to distance to a microedge, i.e., patchy conditions (Rossell et al. 2003, Buehler et al. 2007). We predicted a positive or quadratic response between warbler numbers and residual basal area (Rossell 2001, Roth et al. 2014).

We used an information-theoretic approach to evaluate and rank a priori models explaining variation in Golden-winged Warbler apparent abundance among regenerating stands. Because of time constraints in the field, the sample size for within-stand characteristics $(n=116)$ was lower than stand characteristics $(n$ = 222). Thus, because Akaike's information criterion (AIC) modeling cannot be used to compare models of different data sets (Burnham and Anderson 2002), we generated 2 sets of models, 1 set for stand variables and another for within-stand variables (see Appendix 1). We then ran these sets for the mid-Appalachian and northeast regional scales. To account for spatial autocorrelation across the mid-Appalachian set of models (Moran's $I, Z=29.1$, $P<0.001$ ), we developed generalized linear mixed models (PROC GLIMMIX; Bolker et al. 2009), in which models considered longitude as a random effect and used the Laplace approximation for maximum likelihood estimation. For models in the northeast region, we used generalized linear models (PROC GENMOD) because of a lack of spatial autocorrelation (Moran's $I, Z=0.87$, $P=0.385$ ). Both mid-Appalachian and northeast regional models used a negative binomial distribution to calculate log-likelihood estimates for each model (SAS Institute 1996) because our data had a mean greater than the variance (Schabenberger and Pierce 2002) and it is an effective distribution for count data (White and Bennetts 1996, O'Hara and Kotze 2010, Lindén and Mäntyniemi 2011). We then calculated AIC corrected (AIC ) for bias because of small sample size. The best model has the lowest $\mathrm{AIC}_{c}$ value, and subsequent models were assessed by their difference in $\mathrm{AIC}_{c}$ values $\left(\triangle \mathrm{AIC} C_{c}\right)$ and weight of evidence $\left(w_{i}\right)$. We generated a confidence set of candidate models, in which models with AIC weights within $10 \%$ of the highest weight were included in the confidence set (Royall 1997, Burnham and Anderson 2002). We assessed goodness of fit for the global model by calculating a variance inflation factor $(\hat{c})$, where a $\hat{c}$ close to 1 is considered a relatively good model fit (Burnham and Anderson 2002). Furthermore, we calculated collective weights of evidence by summing $w_{i}$ over all models containing the variable to determine the relative variable importance (Burnham and Anderson 2002). Because of the likelihood of several candidate models being equally parsimonious, we calculated model-averaged parameter estimates and their standard errors (Burnham and Anderson 2002, but see Galipaud et al. 2014).

\section{RESULTS}

We surveyed 222 regenerating stands in Pennsylvania and western Maryland. Throughout our study area, we surveyed 74, 62, and 86 regenerating stands in the north-central, northeast, and southcentral regions, respectively. We surveyed 134 stands in 2010 and 204 stands in 2011, with 36 stands surveyed in both years. Male Golden-winged Warblers were detected in $22.5 \%$ (i.e., 50 of 222) of the regenerating stands, whereas male Blue-winged Warblers and Brewster's Warblers were detected on only 6 and 5 stands, respectively. At regenerating stands where Golden-winged Warbler males were detected, the median number of individuals per survey was 1 but ranged from 1 to 4 . The northeast region had the highest proportion ( 31 of 62 stands; $50 \%$ ) of regenerating stands with male Golden-winged Warbler detections.

\section{Mid-Appalachian analyses}

\section{Stand features}

Across all three study regions, features of regenerating stands differed significantly between stands where Golden-winged Warblers were and were not detected (Wilks' Lambda $F_{7213}=2.34$, $P=0.025)$. In addition, stand features differed among study regions (Wilks' Lambda $F_{14.424}=23.29, P<0.001$ ), where the north-central region had the largest $\left(F_{2218}=34.09, P<0.001\right)$ and youngest $\left(F_{2218}=3.78, P=0.024\right)$ regenerating stands and the surrounding landscape had the least amount of forest cover $\left(F_{2218}=4.40, P=0.013\right.$; Table 1$)$. The south-central region had stands with the smallest mean perimeter-to-area ratio $\left(F_{2218}=\right.$ 42.34, $P<0.001)$ but the greatest amount of urban cover in the landscape $\left(F_{2218}=3.48, P=0.033\right)$. Finally, regenerating stands in the northeast region had the greatest amount of young forest cover within $1 \mathrm{~km}\left(F_{2218}=86.54, P<0.001\right)$. Throughout the study system, the amount of young forest cover was negatively related to elevation $(r=-0.52, P<0.001)$. 
Table 1. Comparison of stand metrics at regenerating stands where Golden-winged Warblers $($ Vermivora chrysoptera $)$ were $(\mathrm{n}=50)$ and were not $(\mathrm{n}=172)$ detected across the region and in each study region: north-central Pennsylvania $(\mathrm{n}=74)$, northeast Pennsylvania $(\mathrm{n}=62)$, and south-central $(\mathrm{n}=86 ; 2010-2011)$ regions. Bold text indicates stand features that differed significantly $(\mathrm{P}<0.05)$ in post hoc univariate tests.

\begin{tabular}{|c|c|c|c|c|c|}
\hline & Detected & Not Detected & North-central & Northeast & South-central \\
\hline Variable & Mean (SE) & Mean (SE) & Mean (SE) & Mean (SE) & Mean (SE) \\
\hline Size of harvest (ha) & $15.7(2.0)$ & $22.0(2.0)$ & $34.8(4.1)$ & $14.0(0.9)$ & $13.2(1.4)$ \\
\hline Years since harvest & $5.6(0.5)$ & $5.3(0.3)$ & $4.7(0.5)$ & $5.2(0.4)$ & $6.2(0.4)$ \\
\hline Mean perimeter-area ratio $(\mathrm{m} / \mathrm{ha})$ & $63.5(5.9)$ & $64.7(3.9)$ & $34.1(1.5)$ & $64.8(5.8)$ & $90.2(6.1)$ \\
\hline Distance to nearest harvest (m) & $148.5(39.8)$ & $255.6(41.4)$ & $347.1(81.0)$ & $218.7(53.1)$ & $141.2(30.6)$ \\
\hline$\%$ forest land cover within $1 \mathrm{~km}$ & $86.6(1.0)$ & $83.6(1.0)$ & $81.1(1.8)$ & $84.7(1.1)$ & $86.6(1.2)$ \\
\hline$\%$ urban land cover within $1 \mathrm{~km}$ & $0.0(0.0)$ & $0.1(0.0)$ & $0.1(0.1)$ & $0.2(0.1)$ & $0.0(0.0)$ \\
\hline$\%$ young forest land cover within $1 \mathrm{~km}$ & $2.8(0.1)$ & $1.6(0.3)$ & $0.9(0.3)$ & $5.7(0.7)$ & $0.0(0.0)$ \\
\hline
\end{tabular}

Golden-winged Warbler abundance at the mid-Appalachian scale was best explained by the proportion of young forest within $1 \mathrm{~km}$ of a regenerating stand and the size of the regenerating stand (Table 2). The relationship between Golden-winged Warbler abundance and proportion of young forest cover was best explained in a concave quadratic relationship in which abundance was greatest between $5 \%$ and $15 \%$ young forest cover (Fig. 2a). This model-averaged parameter estimate confidence interval did not overlap 0 (Table 3 ). Indeed, all of the top 7 models contained the covariate for percent young forest cover and accounted for $87.9 \%$ of the collective $w_{i}$. Abundance of warblers decreased with an increase in the regenerating stand size and was positively related to amount of forest land cover, but neither of these variables had model-averaged parameter estimates that overlapped 0 . Median $\hat{c}$ goodness-of-fit tests indicated a good fit $(\hat{c}=0.97)$.

\section{Within-stand features}

When examining within-stand characteristics at the midAppalachian scale, the model containing the variable proportion of herbaceous cover best explained abundance of the Goldenwinged Warbler in regenerating stands (Table 2 , Akaike weight $=$ 0.27 ). The proportion of herbaceous cover had the highest collective $w_{i}(0.98)$ and was in all of the top models. Goldenwinged Warbler abundance increased as herbaceous cover increased (Fig. 2b). Herbaceous cover within the stand had model-averaged parameter estimates that did not include 0 (Table 3). Four other variables, including the distance to a microedge, shrub cover, number of saplings per hectare, and residual basal area, were included in the confidence set of candidate models (Table 2). Golden-winged Warbler abundance exhibited a quadratic response in which abundance was greatest with approximately $7 \mathrm{~m}^{2} /$ ha residual basal area. Median $\hat{c}$ goodnessof-fit tests indicated a good fit $(\hat{c}=1.05)$.

Across the regions, within-stand features where Golden-winged Warblers were detected were significantly different than those for stands where Golden-winged Warblers were not detected (Wilks' Lambda $F_{5110}=3.48, P=0.006$ ). Regenerating stands where Golden-winged Warblers were detected had greater proportions of herbaceous cover $\left(F_{1114}=13.53, P<0.001\right)$ than those regenerating stands where Golden-winged Warblers were not detected (Table 4). In addition, there was a significant difference in residual basal area $\left(F_{1114}=4.25, P=0.041\right)$, where stands with
Fig. 2. Relationship between apparent abundance index (no. of males/survey $\pm 95 \%$ confidence intervals) of Golden-winged Warblers (Vermivora chrysoptera) in regenerating stands at the mid-Appalachian scale for (a) percent young forest cover within $1 \mathrm{~km}$ and (b) within-stand herbaceous cover and at the northeast regional scale for (c) distance to the nearest timber harvest (m), 2010-2011.
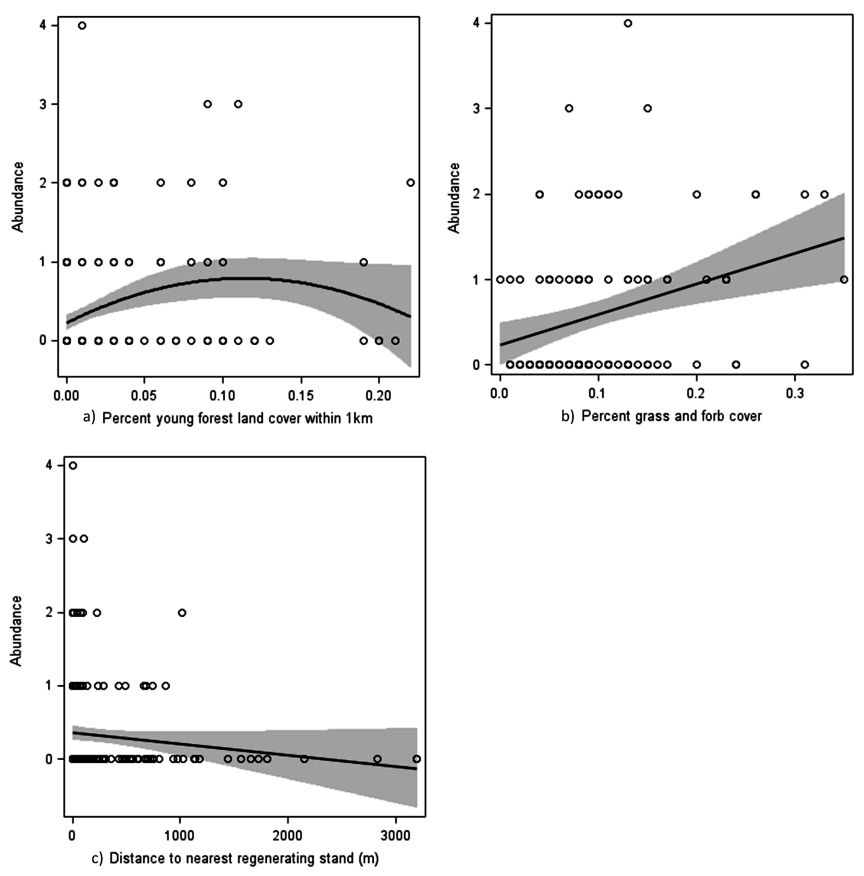

Golden-winged Warbler detections had $6.3 \mathrm{~m}^{2} /$ ha residual basal area compared to $8.3 \mathrm{~m}^{2} /$ ha for stands with no detections. Study regions varied in within-stand features (Wilks' Lambda $F_{10,218}=$ 12.05, $P<0.001)$ where the northeast region had the greatest amounts of $\operatorname{shrub}\left(F_{2113}=23.38, P<0.001\right)$ and shorter distances to a microedge $\left(F_{2113}=9.13, P<0.001\right)$. The south-central region had the lowest residual basal area $\left(F_{2113}=15.73, P<0.001\right)$, and the north-central had the fewest saplings per hectare $\left(F_{2113}=\right.$ 26.51, $P<0.001$ ) compared to the other two regions (Table 4). 
Table 2. Ranked mid-Appalachian, i.e., Pennsylvania and Maryland, and northeast regional models explaining apparent abundance of Golden-winged Warblers (Vermivora chrysoptera) that incorporated stand and within-stand characteristics of regenerating stands, 2010-2011. Only the confidence set of candidate models is included. See Appendix 1 for the full suite of models and explanations of terms used in models.

\begin{tabular}{|c|c|c|c|c|c|}
\hline Model & -2 Log Likelihood & $\mathrm{K}^{\dagger}$ & $\mathrm{AIC}_{+}^{\star}$ & $\Delta \mathrm{AIC}_{\varsigma}^{\S}$ & $w_{i}^{\prime}$ \\
\hline \multicolumn{6}{|l|}{ Mid-Appalachian models } \\
\hline \multicolumn{6}{|l|}{ Stand variables } \\
\hline Abundance $_{(\text {Young forest }+ \text { Size })}$ & 319.04 & 5 & 319.04 & 0.00 & 0.28 \\
\hline Abundance ${ }_{\text {(Young forest }+ \text { Young forest } 2 \text { ) }}$ & 311.29 & 5 & 319.47 & 0.43 & 0.23 \\
\hline Abundance $_{\text {(Young forest / Size) }}$ & 310.31 & 6 & 320.59 & 1.55 & 0.13 \\
\hline Abundance ${ }_{\text {(Young forest }+ \text { Forest }+ \text { Nearest harvest) }}$ & 310.92 & 6 & 321.20 & 2.16 & 0.10 \\
\hline Abundance ${ }_{\text {(Young forest }+ \text { Forest) }}^{(\text {Young forest }}$ & 313.87 & 5 & 322.06 & 3.02 & 0.06 \\
\hline Abundance $_{\text {(Young forest) }}$ & 316.53 & 4 & 322.64 & 3.60 & 0.05 \\
\hline Abundance $_{(\text {Global model })}$ & 304.17 & 10 & 323.02 & 3.98 & 0.04 \\
\hline \multicolumn{6}{|l|}{ Within-stand variables } \\
\hline Abundance $_{(\text {Herbaceous cover) }}$ & 233.27 & 4 & 239.48 & 0.00 & 0.27 \\
\hline Abundance ${ }_{\text {(Herbaceous cover + Microedge) }}$ & 231.73 & 5 & 240.09 & 0.61 & 0.20 \\
\hline Abundance ${ }_{\text {(Herbaceous cover }+ \text { Shrub cover })}$ & 232.25 & 5 & 240.61 & 1.13 & 0.16 \\
\hline Abundance $_{\text {(Herbaceous cover }+ \text { Saplings }+ \text { Microedge) }}$ & 230.46 & 6 & 241.01 & 1.53 & 0.13 \\
\hline Abundance $_{(\text {Herbaceous cover + RBA })}$ & 233.04 & 5 & 241.41 & 1.93 & 0.10 \\
\hline Abundance $_{(\text {Herbaceous cover }+ \text { Shrub cover }+ \text { RBA) }}$ & 231.17 & 6 & 241.71 & 2.23 & 0.09 \\
\hline \multicolumn{6}{|l|}{ Northeast region models } \\
\hline \multicolumn{6}{|l|}{ Stand variables } \\
\hline Abundance $_{\text {(Nearest harvest }+ \text { Forest) }}$ & 109.20 & 4 & 148.06 & 0.00 & 0.25 \\
\hline Abundance ${ }_{\text {(Nearest harvest }+ \text { Urban) }}$ & 109.42 & 4 & 148.28 & 0.22 & 0.22 \\
\hline Abundance ${ }_{\text {(Nearest harvest) }}$ & 111.80 & 3 & 148.38 & 0.32 & 0.21 \\
\hline Abundance ${ }_{\text {(Nearest harvest }+ \text { Young forest }+ \text { Forest) }}$ & 108.80 & 5 & 150.03 & 1.98 & 0.09 \\
\hline Abundance ${ }_{\text {(Nearest harvest }+ \text { MPAR) }}$ & 111.68 & 4 & 150.54 & 2.48 & 0.07 \\
\hline Abundance $_{(\text {Forest })}$ & 115.49 & 3 & 152.06 & 4.01 & 0.03 \\
\hline Abundance $_{\text {(Nearest harvest | Urban) }}$ & 111.34 & 5 & 152.57 & 4.52 & 0.03 \\
\hline \multicolumn{6}{|l|}{ Within-stand variables } \\
\hline Abundance $_{(\text {Herbaceous cover })}$ & 119.18 & 3 & 155.75 & 0.00 & 0.15 \\
\hline Abundance $_{(.)}$ & 121.45 & 2 & 155.81 & 0.06 & 0.14 \\
\hline Abundance (Saplings) $^{()^{\prime}}$ & 119.98 & 3 & 156.55 & 0.80 & 0.10 \\
\hline Abundance $_{(\text {Herbaceous cover + RBA) }}$ & 117.70 & 4 & 156.56 & 0.81 & 0.10 \\
\hline Abundance $_{(\mathrm{RBA})}$ & 120.39 & 3 & 156.97 & 1.22 & 0.08 \\
\hline Abundance $_{\text {(Saplings + Saplings2) }}$ & 118.75 & 4 & 157.61 & 1.86 & 0.06 \\
\hline Abundance $_{(\text {Shrub cover) }}$ & 121.31 & 3 & 157.88 & 2.13 & 0.05 \\
\hline Abundance $_{(\text {Microedge })}$ & 121.40 & 3 & 157.97 & 2.22 & 0.05 \\
\hline Abundance ${ }_{(\text {Herbaceous cover + Microedge) }}$ & 119.15 & 4 & 158.01 & 2.26 & 0.05 \\
\hline Abundance $_{(\text {Herbaceous cover }+ \text { Shrub cover })}$ & 119.15 & 4 & 158.01 & 2.26 & 0.05 \\
\hline Abundance $_{(\mathrm{RBA}+\mathrm{RBA} 2)}$ & 119.73 & 4 & 158.59 & 2.84 & 0.04 \\
\hline Abundance $_{(\text {Herbaceous cover }+ \text { Shrub cover }+ \text { RBA) }}$ & 117.54 & 5 & 158.77 & 3.02 & 0.03 \\
\hline Abundance $_{(\text {Microedge }+ \text { Saplings) }}$ & 119.92 & 4 & 158.78 & 3.03 & 0.03 \\
\hline Abundance $_{(\text {Shrubcover + RBA) }}$ & 120.34 & 4 & 159.20 & 3.45 & 0.03 \\
\hline \multicolumn{6}{|c|}{$\begin{array}{l}{ }^{\dagger} \text { Number of parameters in the model. } \\
{ }^{\ddagger} \text { Corrected Akaike's information criterion adjusted for small sample size relative to number of parameters. } \\
\$ \Delta \mathrm{AIC}_{c} \text { indicating difference in } \mathrm{AIC}_{c} \text { value from that of the best model. } \\
{ }^{\mathrm{A}} \mathrm{Akaike} \text { weight indicating relative support for the model. }\end{array}$} \\
\hline
\end{tabular}

\section{Northeast region analyses}

\section{Stand features}

For the northeast region, the model containing the variables distance to the nearest regenerating stand and percent forest land cover in the landscape best explained Golden-winged Warbler abundance. Distance to the nearest regenerating stand had the highest collective $w_{i}(0.88$; global model fit, $\hat{c}=1.06$; Table 2$)$ and was 3.1 times greater than the collective weight for the percent forest cover in the landscape. Distance to the nearest regenerating stand was in the top five models. As distance to the nearest regenerating stand increased, abundance of Goldenwinged Warblers declined (Fig. 2c). In fact, abundance of Goldenwinged Warblers was $<1$ male per survey when another regenerating stand was $>1500 \mathrm{~m}$ away. Abundance of Goldenwinged Warblers was positively related to the percent forest land cover, but the confidence interval of the model-averaged parameter estimate included 0 . 
Table 3. Predictor variables and model-averaged parameter estimates, standard errors (SEs), and 95\% confidence intervals (CIs) included in models hypothesized to affect Golden-winged Warbler (Vermivora chrysoptera) apparent abundance at mid-Appalachian and northeast regional scales using stand and within-stand variables for regenerating stands in Pennsylvania and western Maryland, 2010-2011. Only the variables from the confidence set of candidate models are included. See Appendix 1 for explanations of terms used in models.

\begin{tabular}{|c|c|c|c|}
\hline Variable & Estimate & SE & $95 \% \mathrm{CI}$ \\
\hline \multicolumn{4}{|c|}{ Mid-Appalachian models } \\
\hline \multicolumn{4}{|c|}{ Stand variables } \\
\hline Young forest & 12.81 & 7.77 & $-2.34-27.97$ \\
\hline Young forest ${ }^{2}$ & -102.95 & 44.51 & $-189.74--16.15$ \\
\hline Size & -0.01 & 0.01 & $-0.02-0.00$ \\
\hline Forest & 1.76 & 1.59 & $-1.34-4.86$ \\
\hline Nearest harvest & 0.00 & 0.00 & $0.00-0.00$ \\
\hline \multicolumn{4}{|c|}{ Within-stand variables } \\
\hline Herbaceous cover & 4.98 & 1.46 & $2.13-7.82$ \\
\hline Microedge & -0.47 & 0.40 & $-1.26-0.32$ \\
\hline Shrub cover & 0.82 & 0.88 & $-0.90-2.54$ \\
\hline Saplings & 0.01 & 0.01 & $-0.01-0.02$ \\
\hline RBA & -0.05 & 0.06 & $-0.17-0.08$ \\
\hline \multicolumn{4}{|l|}{ Northeast models } \\
\hline \multicolumn{4}{|l|}{ Stand variables } \\
\hline Nearest harvest & $-1.75 \mathrm{E}-03$ & 8.11E-04 & $-3.33 \mathrm{E}-03--1.72 \mathrm{E}-04$ \\
\hline Forest & 0.31 & 0.20 & $-0.08-0.69$ \\
\hline Urban & -37.95 & 51.86 & $-139.11-63.21$ \\
\hline Young forest & -0.16 & 0.25 & $-0.65-0.34$ \\
\hline MPAR & $-1.10 \mathrm{E}-03$ & $3.10 \mathrm{E}-03$ & $-7.10 \mathrm{E}-03-0.00$ \\
\hline Forest|Urban & 35.50 & 33.47 & $-30.10-101.09$ \\
\hline \multicolumn{4}{|c|}{ Within-stand variables } \\
\hline Herbaceous cover & 3.53 & 2.22 & $-0.81-7.86$ \\
\hline Intercept & -0.07 & 0.58 & $-1.19-1.05$ \\
\hline Saplings & -0.02 & 0.02 & $-0.06-0.02$ \\
\hline RBA & -0.14 & 0.14 & $-0.40-0.12$ \\
\hline Saplings $^{2}$ & $3.00 \mathrm{E}-04$ & $2.00 \mathrm{E}-04$ & $-9.00 \mathrm{E}-05-6.90 \mathrm{E}-04$ \\
\hline Shrub cover & -0.03 & 1.18 & $-2.32-2.27$ \\
\hline Microedge & 0.13 & 0.64 & $-1.11-1.38$ \\
\hline $\mathrm{RBA}^{2}$ & 0.03 & 0.04 & $-0.04-0.10$ \\
\hline
\end{tabular}

\section{Within-stand features}

For the northeast region, proportion of herbaceous cover best explained Golden-winged Warbler abundance among regenerating stands (global model fit, $\hat{c}=1.21$; Table 2). However, this variable had a model-averaged parameter estimate confidence interval that overlapped 0 (Table 3), and it had a relatively low collective $w_{i}$ (0.39). Thirteen additional models composed of combinations of 4 different variables, i.e., residual basal area, number of saplings per hectare, shrub cover, and distance to a microedge, were included in the confidence set of models, indicating that multiple variables likely explained Golden-winged Warbler response to within-stand conditions.

\section{DISCUSSION}

Creation of habitat for Golden-winged Warblers is critical for the conservation and management of the species in the Appalachian Mountains (Buehler et al. 2007, Confer et al. 2011). Indeed, we have shown that habitat availability at the mid-Appalachian scale is an important driving factor of Golden-winged Warbler abundance in regenerating stands in Pennsylvania and Maryland. Apparent abundance of Golden-winged Warblers was highest between $5 \%$ and $15 \%$ of young forest cover within $1 \mathrm{~km}$. Although it is necessary to provide more young forest on the landscape, i.e., $>5 \%$ land in young forest cover, to attract Goldenwinged Warblers, land managers must be cautious because a loss of older age class forests, e.g., $>80$ years postdisturbance, could have negative consequences for Golden-winged Warblers (Frantz et al., in press). Golden-winged Warbler adults during the nesting season and adults and fledglings during the postfledgling stage used structurally complex, older age class forests (Streby et al. 2012, Frantz et al., in press, Streby, Peterson, Kramer et al., in press). In particular, young fledgling, i.e., <9 days postfledging, survival was negatively associated with nest distance to a forest edge (Streby, Peterson, and Anderson, in press).

Although the amount of forest in the landscape may be critical for Golden-winged Warbler breeding and postbreeding requirements (Thogmartin 2010, Roth et al. 2012), it received little support (i.e., collective $w_{i}=0.21$ ) in our modeling efforts. This result was likely attributable to the fact that little variation existed in forest cover across our study sites where the coefficient of variance was $14.9 \%$ and the majority (i.e., $74 \%$ ) of the sites 
Table 4. Comparison of within-stand metrics in regenerating stands where Golden-winged Warblers (Vermivora chrysoptera) were (n $=47)$ and were not $(n=69)$ detected during point-count surveys across the mid-Appalachian and within the north-central $(n=34)$, northeast $(n=62)$, and south-central $(n=20 ; 2010-2011)$ regions. Bold text indicates within-stand features that differed significantly $(\mathrm{P}<0.05)$ in post hoc univariate tests.

\begin{tabular}{|c|c|c|c|c|c|}
\hline & Detected & Not Detected & North-central & Northeast & South-central \\
\hline Variable & Mean (SE) & Mean (SE) & Mean (SE) & Mean (SE) & Mean (SE) \\
\hline Percent cover in herbaceous vegetation & $13.1(1.3)$ & $8.1(0.1)$ & $10.2(1.5)$ & $10.5(0.7)$ & $8.8(1.9)$ \\
\hline Percent shrub cover & $25.5(2.5)$ & $29.0(2.5)$ & $20.6(4.2)$ & $36.2(1.7)$ & $12.6(2.2)$ \\
\hline Distance to microedge (m) & $0.6(0.0)$ & $0.7(0.0)$ & $0.80(0.78)$ & $0.53(0.03)$ & $0.83(0.08)$ \\
\hline Residual basal area $\left(\mathrm{m}^{2} / \mathrm{ha}\right)$ & $6.3(0.7)$ & $8.3(0.7)$ & $6.4(1.2)$ & $9.2(0.5)$ & $4.0(1.0)$ \\
\hline Number of saplings/ha (<10 cm dbh) & $5333.0(414.8)$ & $5068.4(350.2)$ & 3049.9 (458.9) & $6347.0(300.7)$ & $5158.2(590.1)$ \\
\hline
\end{tabular}

had $>80 \%$ forest cover. Thus, it was difficult to detect the influence of this variable. A wider breadth of landscape-scale forest cover values would need to be surveyed to determine that variable's influence on Golden-winged Warbler abundance. Nonetheless, a recent range-wide study clearly demonstrated the importance of expansive forested landscapes ( $>70 \%$ cover) for Golden-winged Warbler conservation (Roth et al. 2012). Finally, we found that the amount of young forest cover was negatively related to elevation, and this demonstrates the opportunity to increase forest management and restoration of scrub oak barrens at higher elevations in Pennsylvania and western Maryland for Goldenwinged Warblers (for barrens habitat and management guidelines, see Commonwealth of Pennsylvania 2010).

Across the mid-Appalachian area, percent herbaceous cover within a stand best explained abundance of Golden-winged Warblers. The amount of herbaceous cover within a stand was 1.6 times greater in stands where Golden-winged Warblers were detected $(13.1 \%)$ compared to stands where Golden-winged Warblers were not detected $(8.1 \%)$. Our results agree with other studies that have found that establishment of Golden-winged Warbler territories and nest sites is positively influenced by grass or herbaceous cover (Klaus and Buehler 2001, Rossell et al. 2003, Bulluck and Buehler 2008). Herbaceous cover is an important habitat component for Golden-winged Warblers, a groundnesting species, because nests are typically placed on the ground at the base of a cluster of herbaceous vegetation (Confer et al. 2011). However, Aldinger et al. (2015) found a curvilinear relationship between Golden-winged Warbler daily nest survival and grass cover, in which nest survival declined when grass cover exceeded $50 \%$.

Residual basal area was another variable that may have influenced Golden-winged Warbler selection of regenerating stands. Golden-winged Warblers use canopy trees for foraging, song perches, and collecting nesting material, e.g., vine bark and oak leaves (Rossell 2001, Kubel 2005, Confer et al. 2011). Forest edges of regenerating stands can provide these opportunities, but maintaining residual canopy trees throughout a stand allows Golden-winged Warblers to use the entire harvested area for breeding habitat (Huffman 1997, Cumming 1998, Klaus and Buehler 2001, Kubel 2005, Roth et al. 2014). Stands with residual canopy trees have been shown to increase density, male pairing success, and reproductive success of Golden-winged Warblers in Wisconsin (Roth et al. 2014). In Tennessee and North Carolina, Klaus and Buehler (2001) found the median basal area of stands occupied by Golden-winged Warblers was $10 \mathrm{~m}^{2} / \mathrm{ha}$. Golden- winged Warbler abundance was greatest at approximately $7 \mathrm{~m}^{2} /$ ha residual basal area in our study area, and although numbers of residual trees by diameter classes were removed from analyses because they were correlated with residual basal area, in stands with Golden-winged Warblers $19 \%$ of residuals were $10-23 \mathrm{~cm}$ $\mathrm{dbh}, 39 \%$ were $23.1-38 \mathrm{~cm} \mathrm{dbh}$, and $42 \%$ were $>38.1 \mathrm{~cm} \mathrm{dbh}$.

Stand features selected by breeding Golden-winged Warblers for the northeast region differed from those selected at the midAppalachian scale, likely because young forest cover was relatively high in abundance in the northeast region. In this case, the distance to the nearest regenerating stand and percent forest cover in the landscape best explained variation in Golden-winged Warbler abundance. Habitat isolation may cause a decrease in quality because it would limit opportunities for social interactions, such as extrapair copulations (Norris and Stutchbury 2001, Litvaitis 2003). Indeed, a concurrent study in Pennsylvania documented movement of males out of their breeding territories and into other nearby (up to $1.4 \mathrm{~km}$ ) patches of young forest (Frantz 2013). Although researchers have emphasized the importance of clustering or clumping patches of early successional forest, especially in landscapes where little young forest occurs (DeGraaf and Yamasaki 2003), we show that providing nearby patches is also important in regions where relatively high amounts of habitat occur.

Based on the low weights of evidence, we did not find strong support that a single within-stand feature influenced abundance of Golden-winged Warblers in the northeast region. Other studies have demonstrated that within-stand vegetation features are not generalizable among regions, or even among sites within a region (Peterson et al., in press, Terhune et al., in press). Golden-winged Warbler abundance in our northeast region was best explained by herbaceous cover within the regenerating stand. Another within-stand feature that was present in several top models included the number of saplings per hectare, and our values of sapling density fell within the ranges reported by Roth and Lutz (2004). However, some studies document that Golden-winged Warblers selected areas with fewer saplings than random or unoccupied areas (Klaus and Buehler 2001, Bulluck and Buehler 2008), and others demonstrate a positive relationship with sapling stem density (Roth and Lutz 2004, Martin et al. 2007). In essence, when regenerating stands are young, e.g., 0-3 years postharvest, they lack cover and foliage provided by saplings that Goldenwinged Warblers use in foraging. Conversely, when forest regeneration transitions into the stem exclusion stage, e.g., 12+ years postharvest, the sapling cover shades out the understory vegetation used by nesting Golden-winged Warblers. 
Previous studies of Golden-winged Warblers in the Appalachian Mountains range indicate that Golden-winged Warblers remain largely allopatric from Blue-winged Warblers at higher elevations (Confer and Knapp 1981, Bulluck 2007, Patton et al. 2010, Larkin and Bakermans 2012). Indeed, we detected either Blue-winged Warblers or Brewster's Warblers in fewer than $5 \%$ of stands. This is likely because of the fact that we focused our surveys in areas that had a combination of extensive forest cover ( mean $=84.2 \%$ within $1 \mathrm{~km}$ ) at higher elevation (mean $=570 \mathrm{~m}$, range $=275-946$ $\mathrm{m})$. However, we must caution that cryptic hybridization is likely to occur in the Golden-winged Warbler population we studied (Vallender et al. 2009).

\section{MANAGEMENT GUIDELINES}

We believe that the many public landholdings within Goldenwinged Warbler conservation focal areas in the Appalachians can serve as cores or hubs from which to radiate Golden-winged Warbler management outward. Based on our findings, we propose the following management guidelines for land managers in the Appalachian Mountains interested in creating breeding habitat for Golden-winged Warblers using commercial timber operations.

As a rule of thumb, when managing for Golden-winged Warblers in the central Appalachian Mountains, we recommend placing regenerating stands in landscapes with $\geq 70 \%$ forest cover. In addition, locating regenerating stands at elevations $>300 \mathrm{~m}$ will likely reduce potential hybridization with Blue-winged Warblers (Buehler et al. 2007, Larkin and Bakermans 2012, Roth et al. 2012). The forest cover can be in various age classes, but managers should strive for $15 \%$ of the landscape in early successional forest. This recommendation is based on a combination of our results, historical forest cover, and the Golden-winged Warbler conservation plan population goals, which include restoring the population size to the 1980 s level. Based on Forest Inventory and Analysis (U.S. Forest Service) data for Pennsylvania, young forest cover declined (from 19\% to 10\%) between 1978 and 2012 (Alerich 1993, U.S. Forest Service 2015), as have populations of Goldenwinged Warblers in Pennsylvania (Larkin and Bakermans 2012). If breeding habitat is a primary reason for decline, and recent levels of young forest (10-11\%; U.S. Forest Service 2015) are not enough to reverse or stabilize population declines, then young forest levels that more closely match forest cover in the 1970s-1980s are needed. However, we caution that more research is required to understand Golden-winged Warbler response to interspersion and extent of young forest cover. If possible, new regenerating stands should be located near other early successional patches such as barrens, abandoned fields, wetlands, or other regenerating stands that may serve as source populations of Golden-winged Warblers. All recent disturbances, i.e., within the past 15 years, should be taken into consideration when coordinating forest management plans for Golden-winged Warblers. Forests previously disturbed by insect outbreaks, tornadoes, or fires are appropriate places for placement of new regenerating stands. Managers should take advantage of such disturbances by planning future regenerating stands, prescribed fires, or other mechanical disturbances nearby. If large areas of young forest do not exist from previous disturbances, they can be created through active forest management. Clustering regenerating stands within $1-2 \mathrm{~km}$ is recommended. Furthermore, creating multiple and localized regenerating stands over time ensures that when 1 stand succeeds out of quality habitat, i.e., >12 years postharvest, other useable stands remain in the landscape.

Within a stand, we recommend that managers provide habitat for foraging, nesting, and territory delineation activities of Goldenwinged Warblers. These needs can be met by creating or maintaining patchy habitat that provides a mix of interspersed residual trees, saplings, shrubs, forbs, grasses, and bare ground (see Bakermans et al. 2011 for detailed prescriptions; Fig. 3). In particular, managers need to retain an appropriate number of dominant or codominant crown class trees (i.e., 3-12 $\mathrm{m}^{2} /$ ha) with at least $40 \%$ of residuals $>38 \mathrm{~cm}$ dbh. Retention of residual canopy trees has proved an effective management tool to increase breeding density of Golden-winged Warblers within a stand (Roth et al. 2014). Many of the components that collectively create patchy and herbaceous (minimum $10 \%$ ) conditions can occur within a regenerating stand when properly retiring skid trails, haul roads, and landings.

Fig. 3. Example of regenerating stands in Pennsylvania with (a) interspersed residual trees postharvest and (b) a mix of snags, saplings, shrubs, forbs, grasses, and bare ground 3 years postharvest.
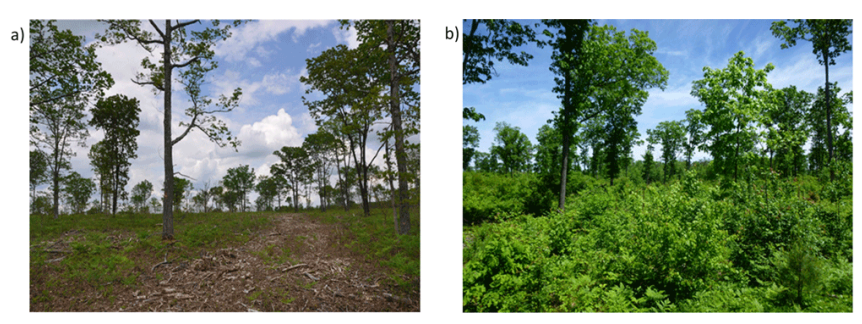

The GWWG's long-term goal is to halt the decline of Goldenwinged Warblers and ultimately double the present-day population by the year 2050, primarily through habitat management. The most important contribution to Goldenwinged Warbler conservation will be to maximize the amount of young forest that can be sustainably managed in Golden-winged Warbler conservation regions, as developed by the GWWG, which are mostly, if not entirely, devoid of Blue-winged Warblers. As such, timber management will be an essential approach to meeting the ambitious early successional habitat goals outlined in the Golden-winged Warbler conservation plan (Roth et al. 2012). Efforts to increase Golden-winged Warbler populations throughout the Appalachians will have the greatest impact and success when following these and other scientifically backed management guidelines (Bakermans et al. 2011, Roth et al. 2012).

Responses to this article can be read online at: http://www.ace-eco.org/issues/responses.php/747

\footnotetext{
Acknowledgments:

We dedicate this manuscript to our friend and coworker, Adam Sabatine, who passed away 19 April 2012. Adam's passion and dedication to avian conservation will be missed. We thank the National Fish and Wildlife Foundation in cooperation with American Bird Conservancy and Appalachian Mountains Joint
} 
Avian Conservation and Ecology 10(1): 10

Venture for providing financial and administrative support for this project. We thank Pennsylvania Department of Conservation and Natural Resources Bureau of Forestry, the Pennsylvania Game Commission, Blooming Grove Hunting and Fishing Club, and Maryland Department of Natural Resources for personnel, resources, and access to their lands. We would also like to thank all the field assistants in data collection: Mack Frantz, Andrea Evans, Brandon Miller, Douglas Gross, Gwen Brewer, James McCann, and Adam Sabatine.

\section{LITERATURE CITED}

Aldinger, K. R. 2010. Playback surveys and breeding habitat characteristics of Golden-winged Warblers (Vermivora chrysoptera) on high-elevation pasturelands on the Monongahela National Forest, West Virginia. Thesis. University of West Virginia, Morgantown, West Virginia, USA.

Aldinger, K. R., T. M. Terhune II, P. B. Wood, D. A. Buehler, M. H. Bakermans, J. L. Confer, D. J. Flaspohler, J. L. Larkin, J. P. Loegering, K. L. Percy, A. M. Roth, and C. G. Smalling. 2015. Variables associated with nest survival of Golden-winged Warblers (Vermivora chrysoptera) among vegetation communities commonly used for nesting. Avian Conservation and Ecology 10 (1):6. http://dx.doi.org/10.5751/ACE-00748-100106

Aldinger, K. R., and P. B. Wood. 2014. Reproductive success and habitat characteristics of Golden-winged Warblers in highelevation pasturelands. Wilson Journal of Ornithology 126:279-287. http://dx.doi.org/10.1676/13-114.1

Alerich, C. L. 1993. Forest statistics for Pennsylvania-1978 and 1989. Resource Bulletin NE-126, U.S. Forest Service, Northeastern Forest Experiment Station, Radnor, Pennsylvania, USA.

Bakermans, M. H., J. L. Larkin, B. W. Smith, T. M. Fearer, and B. C. Jones. 2011. Golden-winged Warbler habitat best management practices for forestlands in Maryland and Pennsylvania. American Bird Conservancy, The Plains, Virginia, USA.

Bakermans, M. H., and A. D. Rodewald. 2006. Scale-dependent habitat use of Acadian Flycatcher (Empidonax virescens) in central Ohio. Auk 123:368-382. http://dx.doi.org/10.1642/0004-8038 (2006)123[368:SHUOAF]2.0.CO;2

Bolker, B. M., M. E. Brooks, C. J. Clark, S. W. Geange, J. R. Poulsen, M. H. H. Stevens, and J.-S. S. White. 2009. Generalized linear mixed models: a practical guide for ecology and evolution. Trends in Ecology and Evolution 24:127-135. http://dx.doi. org/10.1016/j.tree.2008.10.008

Brauning, D. W., editor. 1992. Atlas of breeding birds in Pennsylvania. University of Pittsburgh Press, Pittsburgh, Pennsylvania, USA.

Brawn, J. D., S. K. Robinson, and F. R. Thompson III. 2001. The role of disturbance in the ecology and conservation of birds. Annual Review of Ecology and Systematics 32:251-276. http://dx. doi.org/10.1146/annurev.ecolsys.32.081501.114031

Buehler, D. A., A. M. Roth, R. Vallender, T. C. Will, J. L. Confer, R. A. Canterbury, S. B. Swarthout, K. V. Rosenberg, and L. P. Bulluck. 2007. Status and conservation priorities of Goldenwinged Warbler (Vermivora chrysoptera) in North America. Auk
124:1439-1445. http://dx.doi.org/10.1642/0004-8038(2007)124[1439: SACPOG]2.0.CO;2

Buffum, B., S. R. McWilliams, and P. V. August. 2011. A spatial analysis of forest management and its contribution to maintaining the extent of shrubland habitat in southern New England, United States. Forest Ecology and Management 262:1775-1785. http://dx.doi.org/10.1016/j.foreco.2011.07.024

Bulluck, L. P. 2007. Golden-winged Warbler (Vermivora chrysoptera) demographics and habitat use and the potential effects of land use change on Golden-winged and Cerulean Warblers (Setophaga cerulea) in the Cumberland Mountains of Tennessee. Dissertation. University of Tennessee, Knoxville, Tennessee, USA.

Bulluck, L. P., and D. A. Buehler. 2008. Factors influencing Golden-winged Warbler (Vermivora chrysoptera) nest-site selection and nest survival in the Cumberland Mountains of Tennessee. Auk 125:551-559. http://dx.doi.org/10.1525/auk.2008.07075

Burnham, K. P., and D. R. Anderson. 2002. Model selection and multimodel inference: a practical information-theoretic approach. Second edition. Springer-Verlag, New York, New York, USA. http://dx.doi.org/10.1007/b97636

Commonwealth of Pennsylvania. 2010. Barrens habitat. Pennsylvania Game Commission, Harrisburg, Pennsylvania, USA. [online] URL: http://www.portal.state.pa.us/portal/server. pt/document/1350664/barrens_chapter_pdf

Confer, J. L., K. W. Barnes, and E. C. Alvery. 2010. Golden- and Blue-winged Warblers: distribution, nesting success, and genetic differences in two habitats. Wilson Journal of Ornithology 122:273-278. http://dx.doi.org/10.1676/09-136.1

Confer, J. L., J. Gebhards, and J. Yrizarry. 1998. Golden-winged and Blue-winged Warblers at Sterling Forest: a unique circumstance. Kingbird 39:50-55.

Confer, J. L., P. Hartman, and A. Roth. 2011. Golden-winged Warbler (Vermivora chrysoptera). Number 20 in A. Poole, editor. The birds of North America. Academy of Natural Sciences, Philadelphia, Pennsylvania, USA; and American Ornithologists' Union, Washington, D.C., USA.

Confer, J. L., and K. Knapp. 1981. Golden-winged Warblers and Blue-winged Warblers: the relative success of a habitat specialist and a generalist. Auk 98:108-114.

Confer, J. L., J. L. Larkin, and P. E. Allen. 2003. Effects of vegetation, interspecific competition, and brood parasitism on Golden-winged Warbler (Vermivora chrysoptera) nesting success. Auk 120:138-144. http://dx.doi.org/10.2307/4090148

Cumming, E. E. 1998. Distribution and habitat associations of Golden-winged Warblers in Duck Mountain, Riding Mountain, and Porcupine Hills, Manitoba, 1998. Canadian Wildlife ServiceForest Research Program, Saskatoon, Saskatchewan, Canada.

DeGraaf, R. M., and M. Yamasaki. 2003. Options for managing early-successional forest and shrubland bird habitats in the northeastern United States. Forest Ecology and Management 185:179-191. http://dx.doi.org/10.1016/S0378-1127(03)00254-8

Dettmers, R., D. A. Buehler, J. G. Bartlett, and N. A. Klaus. 1999. Influence of point count length and repeated visits on habitat 
model performance. Journal of Wildlife Management 63:815-823. http://dx.doi.org/10.2307/3802794

Efford, M. G., and D. K. Dawson. 2009. Effect of distance-related heterogeneity on population size estimates from point counts. Auk 126:100-111. http://dx.doi.org/10.1525/auk.2009.07197

Ellison, W. G. 2010. Second atlas of the breeding birds of Maryland and the District of Columbia. Johns Hopkins University Press, Baltimore, Maryland, USA.

Fenneman, N. M. 1938. Physiography of the eastern United States. First edition. McGraw-Hill, New York, New York, USA.

Fike, J. 1999. Terrestrial and palustrine communities of Pennsylvania. Pennsylvania Department of Conservation and Natural Resources, Harrisburg, Pennsylvania, USA.

Frantz, M. W. 2013. Is spot mapping missing important aspects of Golden-winged Warbler (Vermivora chrysoptera) breeding habitat? Thesis. Indiana University of Pennsylvania, Indiana, Pennsylvania, USA.

Frantz, M. W., K. R. Aldinger, P. B. Wood, J. Duchamp, T. Nuttle, A. C. Vitz, and J. L. Larkin. In press. Space and habitat use of breeding Golden-winged Warblers in the central Appalachian Mountains. In H. M. Streby, D. Buehler, and D. E. Andersen, editors. Golden-winged Warbler ecology, conservation and habitat management. Studies in Avian Biology Series. CRC, Boca Raton, Florida, USA.

Friesen, L. E., P. F. J. Eagles, and R. J. Mackay. 1995. Effects of residential development on forest-dwelling neotropical migrant songbirds. Conservation Biology 9:1408-1414. http://dx.doi. org/10.1046/j.1523-1739.1995.09061408.x

Fry, J. A., G. Xian, S. Jin, J. A. Dewitz, C. G. Homer, L. Yang, C. A. Barnes, N. D. Herold, and J. D. Wickham, 2011. Completion of the 2006 National Land Cover Database for the conterminous United States. Photogrammetric Engineering \& Remote Sensing 77:858-864.

Galipaud, M., M. A. F. Gilingham, M. David, and F.-X. Dechaume-Moncharmont. 2014. Ecologists overestimate the importance of predictor variables in model averaging: a plea for cautious interpretations. Methods in Ecology and Evolution 5:983-991. http://dx.doi.org/10.1111/2041-210X.12251

Gregory, R. D., D. W. Gibbons, and P. F. Donald. 2004. Bird census and survey techniques. Pages 17-55 in W. J. Sutherland, I. Newton, and R. E. Green, editors. Bird ecology and conservation: a handbook of techniques. Oxford University Press, Oxford, UK. http://dx.doi.org/10.1093/acprof:oso/9780198520863.003.0002

Hagan, J. M., P. S. McKinley, A. L. Meehan, and S. L. Grove. 1997. Diversity and abundance of landbirds in a northeastern industrial forest. Journal of Wildlife Management 61:718-735. http://dx.doi.org/10.2307/3802179

Huffman, R. D. 1997. Effects of residual overstory on bird use and aspen regeneration in aspen harvest sites in Tamarac National Wildlife Refuge, Minnesota. Thesis. West Virginia University, Morgantown, West Virginia, USA.

Hutto, R. L. 1985. Habitat selection by nonbreeding, migratory land birds. Pages 455-476 in M. L. Cody, editor. Habitat selection in birds. Academic, New York, New York, USA.
Johnson, D. H. 1980. The comparison of usage and availability measurements for evaluation resource preference. Ecology 61:65-71. http://dx.doi.org/10.2307/1937156

Johnson, D. H. 2008. In defense of indices: the case of bird surveys. Journal of Wildlife Management 72:857-868. http://dx. doi.org/10.2193/2007-294

Jones, J. 2001. Habitat selection studies in avian ecology: a critical review. Auk 118:557-562. http://dx.doi.org/10.1642/0004-8038 (2001)118[0557:HSSIAE]2.0.CO;2

Klaus, N. A., and D. A. Buehler. 2001. Golden-winged Warbler breeding habitat characteristics and nest success in clearcuts in the southern Appalachian Mountains. Wilson Bulletin 113:297-301. http://dx.doi.org/10.1676/0043-5643(2001)113[0297: GWWBHC]2.0.CO;2

Kubel, J. E. 2005. Breeding ecology of Golden-winged Warblers in managed habitats of central Pennsylvania. Thesis. Pennsylvania State University, State College, Pennsylvania, USA.

Kubel, J. E., and R. H. Yahner. 2008. Quality of anthropogenic habitats for Golden-winged Warblers in central Pennsylvania. Wilson Journal of Ornithology 120:801-812. http://dx.doi. org/10.1676/06-114.1

Larkin, J. L., and M. H. Bakermans. 2012. Golden-winged Warbler, Vermivora chrysoptera. Pages 350-351 in A. M. Wilson, D. W. Brauning, and R. S Mulvihill, editors. Second atlas of breeding birds in Pennsylvania. Pennsylvania State University Press, University Park, Pennsylvania, USA.

Lindén, A., and S. Mäntyniemi. 2011. Using the negative binomial distribution to model overdispersion in ecological count data. Ecology 92:1414-1421. http://dx.doi.org/10.1890/10-1831.1

Litvaitis, J. A. 2003. Are pre-Colombian conditions relevant baselines for managed forests in the northeastern United States? Forest Ecology and Management 185:113-126. http://dx.doi. org/10.1016/S0378-1127(03)00250-0

Litvaitis, J. A., D. 1. Wagner, J. L. Confer, M. D. Tarr, and E. J. Snyder. 1999. Early successional forests and shrub-dominated habitats: land-use artifact or critical community in the northeastern United States. Northeast Wildlife 54:101-118.

Lorimer, C. G., and L. E. Frelich. 1994. Natural disturbance regimes in old-growth northern hardwoods: implications for restoration efforts. Journal of Forestry 92:33-38.

Martin, K. J., R. S. Lutz, and M. Worland. 2007. Golden-winged Warbler habitat use and abundance in northern Wisconsin. Wilson Journal of Ornithology 119:523-532. http://dx.doi. org/10.1676/06-103.1

Masek, J. G., W. B. Cohen, D. Leckie, M. A. Wulder, R. Vargas, B. de Jong, S. Healey, B. Law, R. Birdsey, R. A. Houghton, D. Mildrexler, S. Goward, and W. B. Smith. 2011. Recent rates of forest harvest and conversion in North America. Journal of Geophysical Research 116:G00K03. http://dx.doi.

org/10.1029/2010jg001471

Masek, J. G., S. N. Goward, R. E. Kennedy, W. B. Cohen, G. G. Moisen, K. Schleeweis, and C. Huang. 2013. United States forest disturbance trends observed using Landsat time series. Ecosystems 16:1087-1104. http://dx.doi.org/10.1007/s10021-013-9669-9 
Norris, D. R., and B. J. M. Stutchbury. 2001. Extraterritorial movements of a forest songbird in a fragmented landscape. Conservation Biology 15:729-736. http://dx.doi.org/10.1046/ j.1523-1739.2001.015003729.x

O'Hara, R. B., and D. J. Kotze. 2010. Do not log-transform count data. Methods in Ecology and Evolution 1:118-122. http://dx.doi. org/10.1111/j.2041-210X.2010.00021.X

Partners in Flight Science Committee. 2013. Population estimates database, version 2013. Rocky Mountain Bird Observatory, Fort Collins, Colorado, USA. [online] URL: http://rmbo.org/ pifpopestimates

Patton, L. L., D. S. Maehr, J. E. Duchamp, S. Fei, J. W. Gassett, and J. L. Larkin. 2010. Do the Golden-winged Warbler and Bluewinged Warbler exhibit species-specific differences in their breeding habitat use? Avian Conservation and Ecology 5(2): 2. http://dx.doi.org/10.5751/ACE-00392-050202

Peterson, S. M., H. M. Streby, and D. E. Andersen. In press. Management implications of brood division in Golden-winged Warblers. In H. M. Streby, D. Buehler, and D. E. Andersen, editors. Golden-winged Warbler ecology, conservation and habitat management. Studies in Avian Biology Series. CRC, Boca Raton, Florida, USA.

Reger, J. P., and E. T. Cleaves. 2008. Explanatory text for the physiographic map of Maryland (version MDPHYS2003.2). Open-File Report 08-03-1, Maryland Geological Survey, Maryland Department of Natural Resources, Baltimore, Maryland, USA.

Rempel, R. S., D. Kaukinen, and A. P. Carr. 2012. Patch analyst and patch grid. Ontario Ministry of Natural Resources, Centre for Northern Forest Ecosystem Research, Thunder Bay, Ontario, Canada.

Robbins, C. S., editor. 1996. Atlas of the breeding birds of Maryland and the District of Columbia. University of Pittsburgh Press, Pittsburgh, Pennsylvania, USA.

Robbins, C. S., D. K. Dawson, and B. A. Dowell. 1989. Habitat area requirements of breeding forest birds of the middle Atlantic states. Wildlife Monographs 103:3-34.

Rodewald, A. D., and M. H. Bakermans. 2006. What is the appropriate paradigm for riparian forest conservation? Biological Conservation 128:193-200. http://dx.doi.org/10.1016/j.biocon.2005.09.041

Rodewald, A. D., and R. H. Yahner. 2001. Influence of landscape composition on avian community structure and associated mechanisms. Ecology 82:3493-3504. http://dx.doi.org/10.1890/0012-9658 (2001)082[3493:IOLCOA]2.0.CO;2

Rossell, C. R., Jr. 2001. Song perch characteristics of Goldenwinged Warblers in a mountain wetland. Wilson Bulletin 113:246-248. http://dx.doi.org/10.1676/0043-5643(2001)113[0246: SPCOGW]2.0.CO;2

Rossell, C. R., S. C. Patch, and S. P. Wilds. 2003. Attributes of Golden-winged Warbler territories in a mountain wetland. Wildlife Society Bulletin 31:1099-1104.

Roth, A. M., D. J. Flaspohler, and C. R. Webster. 2014. Legacy tree retention in young aspen forest improves nesting habitat quality for Golden-winged Warbler (Vermivora chrysoptera).
Forest Ecology and Management 321:61-70. http://dx.doi. org/10.1016/j.foreco.2013.07.047

Roth, A. M., and S. Lutz. 2004. Relationship between territorial male Golden-winged Warblers in managed aspen stands in northern Wisconsin, USA. Forest Science 50:153-161.

Roth, A. M., R. W. Rohrbaugh, T. Will, and D. A. Buehler, editors. 2012. Golden-winged Warbler status review and conservation plan. Golden-winged Warbler Working Group, Michigan Technological University, Houghton, Michigan, USA. [online] URL: http:// www.gwwa.org/resources/GWWAPlanDraft129-LR.pdf

Royall, R. M. 1997. Statistical evidence: a likelihood paradigm. Chapman Hall, London, UK.

SAS Institute. 1996. SAS language version 9.1. SAS Institute, Cary, North Carolina, USA.

Sauer, J. R., J. E. Hines, J. E. Fallon, K. L. Pardieck, D. J. Ziolkowski Jr., and W. A. Link. 2014. The North American Breeding Bird Survey, results and analysis 1966-2012. Version 02.19.2014. U.S. Geological Survey, Patuxent Wildlife Research Center, Laurel, Maryland, USA.

Schabenberger, O., and F. J. Pierce. 2002. Contemporary statistical models for the plant and soil sciences. CRC, Boca Raton, Florida, USA.

Sevon, W. D. 2000. Physiographic provinces of Pennsylvania. Fourth edition. Commonwealth of Pennsylvania, Department of Conservation and Natural Resources, Bureau of Topographic and Geologic Survey, Harrisburg, Pennsylvania, USA.

Smith, E. T. 2007. Early successional habitat. Fish and Wildlife Habitat Management Leaflet No. 41, Natural Resources Conservation Service, Washington, D.C., USA.

Smith, B. W., P. D. Miles, C. H. Perry, and S. A. Pugh. 2009. Forest resources of the United States, 2007. General Technical Report WO-78, U.S. Forest Service, Washington, D.C., USA.

Streby, H., J. P. Loegering, and D. E. Andersen. 2012. Spotmapping underestimates song-territory size and use of mature forest by breeding Golden-winged Warblers in Minnesota, USA. Wildlife Society Bulletin 36:40-46. http://dx.doi.org/10.1002/ wsb. 118

Streby, H. M., S. M. Peterson, and D. E. Andersen. In press. Golden-winged warbler fledgling habitat use and survival in the western Great Lakes region. In H. M. Streby, D. Buehler, and D. E. Andersen, editors. Golden-winged Warbler ecology, conservation and habitat management. Studies in Avian Biology Series. CRC, Boca Raton, Florida, USA.

Streby, H. M., S. M. Peterson, G. R. Kramer, and D. E. Andersen. Post-independence fledgling ecology in a migratory songbird: implications for breeding-grounds conservation. Animal Conservation, in press. http://dx.doi.org/10.1111/acv.12163

Terhune, T. M., K. R. Aldinger, D. A. Buehler, J. L. Confer, D. J. Flaspohler, J. L. Larkin, J. P. Loegering, K. L. Percy, A. M. Roth, C. Smalling, and P. B. Wood. In press. Golden-winged Warbler nest-site habitat selection. In H. M. Streby, D. Buehler, and D. E. Andersen, editors. Golden-winged Warbler ecology, conservation and habitat management. Studies in Avian Biology Series. CRC, Boca Raton, Florida, USA. 
Thogmartin, W. E. 2010. Modeling and mapping Golden-winged Warbler abundance to improve regional conservation strategies. Avian Conservation and Ecology 5(2): 12. http://dx.doi. org/10.5751/ace-00426-050212

Thompson, F. R., III, and R. M. DeGraaf. 2001. Conservation approaches for woody, early successional communities in the eastern United States. Wildlife Society Bulletin 29:483-494.

Toms, J. D., F. K. A. Schmiegelow, S. J. Hannon, and M. A. Villard. 2006. Are point counts of boreal songbirds reliable proxies for more intensive abundance estimators? Auk 123:438-454. http://dx.doi.org/10.1642/0004-8038(2006)123[438: APCOBS]2.0.CO;2

U.S. Forest Service. 2015. EVALIDator version 1.6.0.02. Forest Inventory \& Analysis National Office, U.S. Forest Service, Washington, D.C., USA. [online] URL: http://apps.fs.fed.us/ Evalidator/evalidator.jsp

Vallender, R., S. L. Van Wilgenburg, L. P. Bulluck, A. Roth, R. Canterbury, J. Larkin, R. M. Fowlds, and I. J. Lovette. 2009. Extensive rangewide mitochondrial introgression indicates substantial cryptic hybridization in the Golden-winged Warbler (Vermivora chrysoptera). Avian Conservation and Ecology 4(2): 4. [online] URL: http://www.ace-eco.org/vol4/iss2/art4/

White, G. C., and R. E. Bennetts. 1996. Analysis of frequency count data using the negative binomial distribution. Ecology 77:2549-2557. http://dx.doi.org/10.2307/2265753

Wilson, A. M., D. W. Brauning and R. S. Mulvihill, editors. 2012. Second atlas of breeding birds in Pennsylvania. Pennsylvania State Press, University Park, Pennsylvania, USA.

Zarr, J. H. 1999. Biostatistical analysis. Prentice Hall, Upper Saddle River, New Jersey, USA.

Editor-in-Chief: Keith A.Hobson Subject Editor: Steven L.Van Wilgenburg
Sponsored by the Society of Canadian Ornithologists and Bird Studies Canada Parrainée par la Société des ornithologistes du Canada et Études d'oiseaux Canada

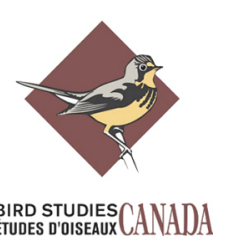


Appendix 1. Candidate models used in stand and within-stand analyses.

Table A1.1. Descriptions of the full suite of candidate models and their parameters describing an apparent abundance index of Golden-winged Warblers in regenerating stands in Pennsylvania and western Maryland, 2010-2011. Constant abundance models (Abundance (.)) contain the intercept only and global models (Abundance(global)) contain all parameters. Vertical bar represents a model that includes main effects and interactions between variables.

\begin{tabular}{|c|c|}
\hline Stand models & Within-stand models \\
\hline Abundance $_{(.)}$ & Abundance $()$. \\
\hline Abundance $_{\left(\text {Young forest }^{\dagger}\right)}$ & Abundance $_{(\text {Herbaceous cover }}{ }^{\ddagger \neq}$ ) \\
\hline Abundance $_{\left(\text {Forest }^{\ddagger}\right)}$ & Abundance $\left._{(\text {Shrub cover }}{ }^{\S \S}\right)$ \\
\hline Abundance $_{\left(\text {Urban }^{\S}\right)}$ & Abundance $_{(\text {Microedgell) }}$ \\
\hline Abundance(Agel) & Abundance (Saplings ${ }^{\mathbf{\top} \uparrow}$ ) \\
\hline Abundance $\left._{(\text {Nearest harvest }}{ }^{\mathbb{T}}\right)$ & Abundance $_{\left(\mathrm{RBA}^{\# \#}\right)}$ \\
\hline Abundance $_{\left(\text {MPAR }^{\#}\right)}$ & Abundance (Saplings + Saplings²) \\
\hline Abundance $_{\left(\text {Size }^{\dagger \dagger}\right)}$ & Abundance $\left._{(\mathrm{RBA}}+\mathrm{RBA}^{2}\right)$ \\
\hline Abundance $_{\left(\text {Young forest }+ \text { Young forest }{ }^{2}\right)}$ & Abundance (Herbaceous cover + Microedge) \\
\hline Abundance $\left(\right.$ Age $\left.+\mathrm{Age}^{2}\right)$ & Abundance (Herbaceous cover + Shrub cover) \\
\hline Abundance $_{\left(\mathrm{MPAR}+\mathrm{MPAR}^{2}\right)}$ & Abundance $_{(\text {Herbaceous cover + RBA) }}$ \\
\hline Abundance $_{(\text {Young forest + Forest) }}$ & Abundance $_{(\text {Shrub cover + RBA) }}$ \\
\hline Abundance $_{(\text {Young forest }+ \text { Size })}$ & Abundance (Microedge + Saplings) \\
\hline Abundance $_{(\text {Forest }+ \text { Urban) }}$ & Abundance (Microedge + Shrub cover) \\
\hline Abundance $_{\text {(Forest }+ \text { Nearest harvest) }}$ & Abundance $_{(\text {Shrub cover | Saplings) }}$ \\
\hline Abundance $_{(\text {Urban }+ \text { Size })}$ & Abundance $_{(\mathrm{RBA} \mid \text { Saplings })}$ \\
\hline Abundance (Urban + Age) & Abundance (Herbaceous cover + Shrub cover + RBA) \\
\hline Abundance (Urban + Nearest harvest) & Abundance $($ Herbaceous cover + Saplings + Microedge) \\
\hline Abundance $_{(\text {Age }+ \text { MPAR) }}$ & 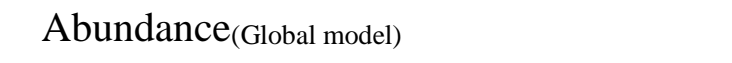 \\
\hline \multicolumn{2}{|l|}{ Abundance $_{\text {(Nearest harvest + MPAR) }}$} \\
\hline \multicolumn{2}{|l|}{ Abundance $_{(\text {Age } \mid \text { MPAR) }}$} \\
\hline \multicolumn{2}{|l|}{ Abundance $_{(\text {Young forest | Size) }}$} \\
\hline \multicolumn{2}{|l|}{ Abundance (Size $\mid$ MPAR) } \\
\hline \multicolumn{2}{|l|}{ Abundance (Nearest harvest | Size) } \\
\hline \multicolumn{2}{|l|}{ Abundance $_{(\text {Forest } \mid \text { Urban) }}$} \\
\hline \multicolumn{2}{|l|}{ Abundance (Urban $\mid$ Age) $_{4}$} \\
\hline \multicolumn{2}{|l|}{ Abundance $_{(\text {Young forest }+ \text { Forest }+ \text { Nearest harvest) }}$} \\
\hline 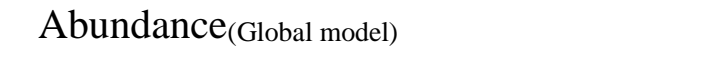 & \\
\hline
\end{tabular}

${ }^{\dagger}$ Young forest $=\%$ young forest land cover within $1 \mathrm{~km}$

${ }^{\ddagger}$ Forest $=\%$ mature forest land cover within $1 \mathrm{~km}$ 
${ }^{\S}$ Urban $=\%$ urban land cover within $1 \mathrm{~km}$

IAge $=$ Years since harvest

"Nearest harvest $=$ Distance to nearest harvest $(\mathrm{m})$

${ }^{\#}$ MPAR = Mean perimeter area ratio (m/ha)

${ }^{\dagger \dagger}$ Size $=$ Size of harvest (ha)

${ }_{\ddagger}^{\ddagger}$ Herbaceous cover $=\%$ cover in herbaceous vegetation

$\S \S$ Shrub cover $=\%$ cover in shrubs

${ }$ Microedge = distance to microedge (m)

${ }^{\text {"⿻ }}$ Saplings = Number of saplings/ha

${ }^{\# \#} \mathrm{RBA}=$ residual basal area $\left(\mathrm{m}^{2} / \mathrm{ha}\right)$ 